\title{
Quotidian of accompanying family members in an environment of care: the emergence of hospital tribes*
}

\author{
Quotidiano de familiares acompanhantes nos cenários de \\ cuidado: o emergir das tribos hospitalares \\ Cotidiano de familiares acompañantes en los escenarios de \\ cuidado: el emerger de las tribus hospitalarias
}

Silvia da Silva Santos Passos ${ }^{1}$, Álvaro Pereira², Rosane Gonçalves Nitschke ${ }^{3}$

How to cite this article:

Passos SSS, Pereira A, Nitschke RG. Quotidian of accompanying family members in an environment of care: the emergence of hospital tribes. Rev Esc Enferm USP. 2016;50(3):464-471. DOI: http://dx.doi.org/10.1590/S0080-623420160000400013

\begin{abstract}
* Extracted from the thesis "Quotidiano de familiares acompanhantes de pessoas hospitalizadas com dependência para o autocuidado", Escola de Enfermagem, Universidade Federal da Bahia, 2015.

${ }^{1}$ Universidade Estadual de Feira de Santana, Feira de Santana, BA, Brazil.

${ }^{2}$ Universidade Federal da Bahia, Escola de Enfermagem, Salvador, BA, Brazil.

${ }^{3}$ Universidade Federal de Santa Catarina, Florianópolis, SC, Brazil.
\end{abstract}

\begin{abstract}
Objective: Understand the quotidian relationships of accompanying family members in an environment of care, which are close to the metaphor of a tribe in hospital environment. Method: Qualitative study with data gathered from semi-structured interviews and observations with 16 family members accompanying hospitalized individuals with dependence on self-care. Data were submitted to thematic analysis, and analyzed through the metaphor of "tribe" proposed by comprehensive sociology. Results: Family members build up social clusters around caring, where we find traits typical of tribes: emotional ambience; solidarity based on links of sympathy and mutual assistance; an affectual nebula in the process of interaction; a logic of fusion in tactile relations; and communion/ religiosity in the process of connecting in a collective identity. Conclusion: In the presence of tragedy, families build social clusters similar to tribes having care as a totem.
\end{abstract}

\section{DESCRIPTORS}

Family; Family Relations; Hospitalization; Caregivers; Community-Institutional Relations. 


\section{INTRODUCTION}

The family system is composed by interrelated and interconnected elements that exist in permanent interaction. The behavior of those involved in this system, regardless of whether independent or as a set, receives feedback from environmental systems. Depending on their functions, individuals interact with one another and with the environment, creating a structure that is changed according to the type of interaction and environmental changes. In this way, when a family member changes the behavior, such as in disease, many times it leads to great tension or anxiety among other members of the family that typically react to this change ${ }^{(1)}$, positively or negatively.

A study carried out with family caregivers of people with brain tumor found that the caregiver family member, during the disease process, unfolds changes on the family dynamics and on relationships and roles in the family system, mainly when accompanying the diseased person in the hospital environment ${ }^{(2)}$.

In the light of comprehensive sociology, the family's permanence in the hospital to accompany a relative triggers the vital instinct, that is, that configured as the need for establishing types of sociality specific to time/space. Sociality is exercised in different social environments where actions, interactions, and exchanges with those living in the same space $^{(3)}$ take place.

The place is perceived as a space that carries the notion of forced belonging because subjects interacting in it cannot always select the place where they want to be. In this sense, aspects focused on the institutionalized place-space allow for building the link ${ }^{(3)}$.

In this context, in situations of hospitalization, family members get organized to stay as long as possible with their relatives, becoming part of the institutional routine and recognized as key parts of this routine. These family members play different roles and responsibilities regarding care in these environments ${ }^{(4)}$.

The place also comprises everything related to the feeling of belonging reinforced by the emotional sharing. Place/ space belongs to the order of ambience serving as a linking element, a sort of societal cement among people living in society ${ }^{(3)}$.

In this sense, place corresponds to the environment of care shared by family members of hospitalized individuals, while the hospital environment belongs to the order of ambience involving the space climate named "hospital." This study approaches ambience based on notions of the theoretical referential, where ambience is related not only to the architectural and structural space, but also to the aesthetic environment prepared for all activities developed by individuals.

Ambiences of time and place influence everyday activities, and are the matrix that determines rational doing. As such, these are efficacious to generate a collective body. However, history teaches us other equally important situations that express the reconnection enabled by the feeling of relationship, the feeling induced by a place in a given time ${ }^{(5)}$.
The role played by family members in hospital environments is not clearly defined. Family members are present not only because they need to accompany and support their relative, but also because the institution's nursing team asks them to. Family caregivers point out that activities developed in the hospital meet the objective and subjective dimensions of care. Objective care comprise activities such as bathing, dressing, and giving food, while the subjective care is related to love, affection, and companionship ${ }^{(6)}$.

Accompaniment and care delivered by family members in collective settings favor their everyday socialization and the sharing of common problems, triggering a relationship of closeness and solidarity through mutual assistance in the provision of care.

In this light, the accompanying family member in the hospital environment builds relationships that favor the being-together with other subjects external to the family group of origin, building new contemporary clusters structured by the affectual dimension, gathered by solidarity links that may culminate in the establishment of tribes.

In the light of interpretative sociology, these contemporary clusters correspond to the metaphor of tribe. In these sets of subjects interacting, individualism is rejected and the individual is compelled to live in groups. In this light, we aimed to understand the everyday relationships of accompanying family members in the environment of care, which are close to the metaphor of tribe in the hospital environment. In the institutionalized environment, the family members' common need to take care of their relatives takes them to a kind of solidarity typical to the place, building a specific social group grounded on emotional reason.

In this way, the metaphor of tribe advocates that postmodern times have no place for individualism; people live and socialize in social clusters, in micro-groups and groups that make up the baseline society. These groups belong to the order of political, fusion, tactile relations, and sympathy relations ${ }^{(3)}$.

Clusters of political order are focused on social existence, allied and submitted to injections of multiform power. In these groups, individuals are privileged according to their contractual and rational links ${ }^{(3)}$.

While the order of fusion is strengthened according to its affective and sensitive dimension, relationships are based on dialogue and exchange and can be de-individualizing, where a kind of stippled union is built; that is, interactions still happen and are crystallized and groups are assembled even without the extensive presence of the other. Technical relations occur in a special environment, and are flexible and firm at the same time; these relations are being nurtured similarly to those established by social networks, sports, and music groups ${ }^{(5)}$.

The bonds of sympathy are characterized by elective affinities, organic meeting, and affectual links, and are structured as a group through contamination. These are the most approached herein. The basis of these relations is face-toface communication. Empathy is the social existence as a whole, regardless of whether through contract, perception, or sight. The relation of sympathy always bears some 
sensitive trait that is influenced by the environment and its appearance, which are aggregation factors ${ }^{(3)}$.

In the context of tribes, people play different roles in society, either in their professional activity or in the different tribes where they participate. This performance corresponds to masks (facies) and, in this way, everyday life is compared to a spectacle, a theatricality where different roles are crucial to the group stability (tribe).

Another aspect found in social aggregations refers to the emotions and religiosity that make up an emotional community. Religiosity here should be understood in the sense of connection. It is in this community that social network links take place, where individuals privilege both oral and non-oral communication, appraising silent situations ${ }^{(3)}$.

Urban tribes share interests through a totem that is the logic of social attraction, of connection between people, defining the way this aggregation takes place. The totems existing in the imagery of tribes give rise to human histories and ground social ties. The clear identification of totems in these clusters grants importance and strengthens the everyday rituals; that is, the whole social cluster is built around affinities ${ }^{(5)}$.

Tribes have their own ethics lived in the present that is much stronger than the universalist moral of democracy. In this way, groups formed by elective affinities have their own code of honor, and support and defend one another ${ }^{(3)}$.

Affectivity found in sympathy-based clusters is based on the logic of network, where otherness is responsible for the processes of attraction and repulsion. Another modulation of tribalism is represented by the "multicellular masses endowed with cohesion, with an organic concept per excellence through blood kinship"(3), represented by the family with inbreeding ties ${ }^{(3)}$. This way, the individual today is part of several tribes that cross with each other at the same time, as in an undifferentiated mass with largely diversified polarities $^{(5)}$.

The multiplicity of tribes that proliferate in culture, in institutions, or in the everyday life and the spirit of family found in these clusters is a standard that has fostered the development of surveys ${ }^{(5)}$.

By using the metaphor of tribe, this study intends to contribute towards understanding the everyday lives of these families to expand the discussion about planning of family participation in the hospital environment of care; foster nursing professionals to consider the family member as an actor in its practice; and enable healthier relations, thus facilitating nursing care that is more sympathetic and sensitive to the relative/companion of the hospitalized individual who is dependent for self-care.

\section{METHOD}

This is a descriptive and exploratory study with a qualitative and comprehensive approach carried out in a public education hospital in the inlands of Bahia, and was approved by the Committee of Ethics in Research with Human Beings, protocol \# 623 495/2014. The study participants were family members that met the following criteria: be accompanying adult and aged individuals with dependence for self-care (eating, personal care, mobility); be more than 18 years old; be accompanying relatives; and be in collective rooms. The only exclusion criterion was obtaining financial advantages for accompanying the hospitalized individual.

Although no minimum length of accompaniment has been defined, it was established at least two days and no more than six months, which was the time period corresponding to that of hospitalization.

Data were collected from May to June 2014 at the medical and neurological clinics because these reported higher concentrations of adult and aged individuals with dependence for self-care, accompanied by family members. Three scenarios (collective rooms) were eligible for the study because the met the criterion of having all beds occupied by adult and aged individuals with dependence for self-care related to mobility, eating, and personal care during the data collection period.

A semi-structured interview with a script and direct observation was used as the data collection technique. Interviews lasted 30 minutes on average, and were conducted in a place accessible only to the researcher and the participant. Participants answered the following questions: How is your relationship with other companions? Tell me about these relationships.

The relational dynamics were recorded on the observation script. We observed in the daily routine of family members: approaches; repetitions; interactions; solidarity; exchanges; and similarities and differences in scenarios. Observation let us identify and understand the links established between those involved with care.

All accompanying family members in the scenarios were invited, totaling 20; however, four refused to participate. In scenario I, one person was eventual companion and did not feel comfortable to participate and another, although the daughter of a hospitalized individual, said she did not want to participate in interviews. In scenario II, one person was in emotional and psychological suffering, and another would not leave her relative because he was agitated. In scenario III, all family members accepted to participate.

Although the scenarios observed had people with dependence on self-care referring to mobility, eating, and personal care accompanied by relatives, these have different characteristics. In scenario I, the hospitalized individuals were elderly. The relationship comprises much more than just care of the body; care always abounded in attention and zeal. The codename assigned to the participants in this scenario was the name of flowers. In scenario II, resistance was the main characteristic. Family members did not conform to the situation, sometimes rebelling, but resisted adversity and remained fighting for procedures, surgeries, and transfers. Their codenames were the names of gemstones. In scenario III, the accompanying family members were codenamed with the name of birds because, despite the tragedy in their lives, they resisted and hoped for good outcomes for their relatives.

Data obtained in interviews were recorded and further transcribed. After exhaustive reading, data were decoded and submitted to comprehensive thematic analysis, 
discussed through the metaphor of tribe in the light of comprehensive sociology.

Through the metaphor of tribe the author freely supports his thoughts, and is satisfied in just describing and understanding the phenomenon, not minding with explanations about it. In this light, the metaphor does not unequivocally indicate the sense of things, but helps perceiving their meanings ${ }^{(2)}$.

\section{RESULTS}

Sixteen actors participated in the study, and were divided into three collective rooms that we called scenarios: In Scenario I, five actors participated, of whom four were women and one man; they were three daughters, one husband, and one granddaughter. Ages ranged between 29 and 62 years old. In Scenario II, five accompanying family members participated in the study, all women; they were two sisters, one daughter, one sister-in-law, and one wife, with ages ranging from 21 to 53 years. In Scenario III, there were six participants, where two were fathers, three were mothers, and one was an aunt, with ages ranging between 46 and 51 years.

Using the thematic analysis and the metaphor of tribe for categorization, two speeches came about:

Emotional ambience. In the hospital environment the process of interaction between accompanying family members happened because of the common situations experienced when living in the same place/space. This way, they build a relationship of affection, typical around the being together in situations of disease and hospitalization of their relatives.

To fit into the environment, the family member assumes behavioral postures as the sublimation of personal problems, listening to the other, preventing conflicts, adopting gestures of fellowship and kindness that facilitate living together in the spaces of care.

We try to keep that thing pleasant, because the place is bad enough to make it unpleasant. We do what we can to get fit to the situation, because that becomes our house, whether we like it or not. Make things pleasant so we can stand it (Dalia - Scenario I).

I try to treat everyone well. I hardly get stressed because my problems at home I leave at home, of my work I leave there, when I get here, I'm myself, with no problems, no nothing (Camellia - Scenario I).

If someone comes with harsh speech, I let it go, I'm not aggressive, I wait a while until the person feels and sees it is her mistake, you see? (Emerald - Scenario II).

The inevitable permanence in an environment different from the usual leads the accompanying family member to become adjusted and change relations in this place/space, making it as similar as possible to their place of origin.

This way, despite the use of behavioral devices to facilitate the interaction process, these family members become organized because they get together, support each other, and are sympathetic in the actions and emotions shared. This organization is justified by the presence of tragedy in the diseasing process of people in situations of hospitalization.

Solidarity is usual among these family members; they meet and get closer around the care provided to their relatives, relate through difficulties and suffering, share feelings, collectively share experiences, and build bonds of friendship.

It is one helping the other... all... all these people suffer, you know? Living together there one supports the other, one helps the other, you see? A person hurt, but that has some happiness, because each person has a kind of problem. But, in brief, the problem is the same, because no one wanted to be in the hospital in a room like that, so we talk... these are kind people, humble people... (Eagle - Scenario III).

Well, we talk about the suffering of people here, of being there accompanying the patients. (Parrot - Scenario III)

Speeches show the affectual relationships between accompanying individuals who had never met prior to the hospitalization of their family members. These relationships resemble the family relationships and interaction, where empathic links and care prevail among members. Friendships are built in the everyday interactions.

Solidarity/sympathy emerges as a need, as a network of support and strength to cope with the diseases of their beloved ones. Solidarity was shown by getting closer and establishing friendship bonds.

Friendship started here, they are from Ipecaetá, left their phone number, the sister-in-law and the wife gave us their phone number so we can talk, tell the news (...) (Ruby - Scenario II).

It becomes a community of companions, everyone keeps in touch. Calls, how things are going? Got better? Even from other cities, surrounding cities, they call (Dalia - Scenario I).

Everybody is friend, it is a family, because when we need, the other is there to help, and when they need me, I'm also there to reach out a belping hand (Thrush - Scenario III).

(...) when we need, we help each other, we help. Sometimes the fan that I'm not using, I loan it, I ask not to turn it to her. Sometimes, the light is off, one helps, light on is good to me, bad to the other, so we alternate, sometimes on, other times off (Emerald - Scenario II).

The community of companions mentioned in the participant's testimonial plays the role of a solidarity-based supporting network. The exchange of experiences, the sharing of feelings and exchange of materials and equipment promote comfort for themselves and for their relatives during hospitalization.

However, as is typical when living in collectivity, these relations are not always harmonious. As such, we have identified conflicts and divergences in the process of living in the same space which gave rise to the affectual nebula category.

The affectual nebula was identified in the social bonds established between the accompanying family members in the emotional community, where instability is joined with the relational. This happens in situations where the companions 
work on solidarity to provide care, but feel no reciprocity from others when they need help, or when not everyone cooperates to keep the environment in conditions favorable to the night rest. Sometimes, conflict may result from the perception of invasion of privacy that they qualify as gossips.

Each one respects the other's work... I help some, but someone to help me, I see no one... And I am not the kind of person that asks. Sometimes I ask to raise him, ask to put the cushion, pillow. Talk and then we take a nap on the chair. Sometimes I get mad because of the light, they leave it on and it hits my eyes, and the person is with this head condition and can't, you see? The girls come and turn it off (Diamond - Scenario II).

I joke and all, but I don't get involved, I don't want to know their businesses; people gossip, but I'm fine with everyone, thanks God (Dalia - Scenario I).

The alternation between the interaction and relationship between accompanying family members, empathic stability, and instability is a consequence of the communication process. In this space this communication used to be face-toface, with body language and through the use of technological resources. The use of technological resources gives rise to the other category, the logic of fusion/tactile relationship.

In the logic of fusion/tactile relation, the accompanying family members use resources such as cell phones and applications like the WhatsApp to communicate with their sons, partners, and other accompanying persons who have already been discharged from hospital.

I have the phone number of who leaves; I call to know the news. We have a problem, I call. There is the daughter of a companion that is sewing for me; yesterday she called me: "Your things are ready" (Camellia - Scenario I).

If you talk on the phone, everybody knows, if you have a problem everyone feels, it is like an antenna, you see? (Dalia-Scenario I).

Everyone needs the other. I have friendships, we exchanged phone numbers to keep in touch. Those who left, we always call; sometimes they call us (Amethyst - Scenario II).

The use of technology enables relationships and the participation in the group outside of the hospital. We could observe that family members administer their domestic problems with sons and partners by phone, use Internet tools through WhatsApp to show, in real time, the situations they experience in the scenarios of care, with pictures and videos.

Diversity in the communication process does not weaken the relational aspects, but is used as a way to strengthen the link between these persons. This connection gives rise to a category named communion/religiosity, understanding religiosity in the sense of connection.

Communion/religiosity was observed in the social group created in the institutionalized place/space. In these spaces beliefs are shared through the socialization of people that think and feel similarly. This collective identity refers to "us," a core aspect to live in a group.

In this way, long times spent together and coping with the same difficulties imposed by the disease of their relatives awaken a feeling of belonging in participants.
We bring food to the others. There is a man that stays 24 hours with his wife; he doesn't go home, and the food here is not enough to a man. So we bring, and he goes out there to eat. One day I had to buy a medicine for my grandmother; she had to take one pill only, and her mother needed, too. We bought and shared. When one asks for diapers, we take to all four; we are allied (Acacia-Scenario I).

(...) it is one helping the other, if one needs to turn, change the sheet, change a diaper, if we bring something like water, if one needs, gives to the other. We keep good relationships, thanks God. We become a family there in the room. I guess no one has any problem with no one, thanks God (Begonia - Scenario I).

We make lots of friendships here. Some even cry when go away. Make lots of friends. Help each other (Parrot - Scenario III).

Oh, my relationship is great, I have a booklet here; it is full of phone numbers. (Ruby - Scenario II)

The group is assembled based on relationships and interactions, where affinities are identified. Closeness with accompanying family members in the scenarios of care, regardless of the traits of such scenarios, cooperates to a being-together that electively favors clustering. In this way, we are able to describe the scenarios of care as tribes, because we found these characteristics of the metaphor of tribes in the light of comprehensive sociology.

\section{DISCUSSION}

The results showed the influence and representation of the hospital environment on the everyday lives of the families during their process of accompanying relatives. In this sense, we found that disease and disability are experiences that represent one of the main challenges to families. The psychosocial problems caused by a person with dependence has impact on the whole family system ${ }^{(7)}$.

The hospital environment/space has its meaning established through the values and beliefs of a culture. The hospital symbolism shows its density in the imagery of those attending it and in both individual and collective memories, becoming a place of feelings and familiarities. The imagery corresponds to this world of meanings, ideas, fantasies, evocation of figures perceived or not, beliefs, and values where the human being is immersed ${ }^{(8)}$.

A hospital environment involves linkages, accountability, and compassion ${ }^{(7)}$. In this way, changing the relations in these spaces is joined with the intrinsic characteristics of the environment that is on the baseline of knowledge and emotional phenomena, in a situation where one is connected to the other and, at the same time, lives with the other, where everything is dependent and interdependent, in an empathic relation. A relationship grounded on empathy results in exchanges of feelings and emotions, ensuring communication and effective support ${ }^{(9)}$.

The accompanying family members interact and relate in a moment when we see the replacement of rationalized social by a sociality where empathy prevails. Sociality appears in the dynamics of relationships, rejecting all forms of organization, and being structured in the everyday. This 
is a phenomenon known as "emotional ambience"(3).

The emotional ambience related to accompanying a family member refers to the feelings, emotions, and care experienced in the hospital place/space at the moment when they realize the process of their relative's disease and why they are hospitalized. In these spaces, the emotional ambience occurs by means of mechanisms of contagion of mutual feelings and emotions. This closeness favors different forms of social aggregation ${ }^{(2)}$.

Contagion occurs though interaction in the hospital environment among people sharing experiences and suffering, such as chronic disease. In this light, an empirical study about solidarity in Latin America affirms that a solidarity network is not built exclusively from the action of a subject bearing the expectation of collaboration, but also from the expectation of the person being helped. Solidarity is used to achieve inclusion in social systems. This perspective demands not only the participation of the suffering ones but also, and above all, the addressee of the actions of solidarity $^{(10)}$.

In this way, the everyday life of an accompanying family member, in an analogy to the comprehensive idea, is similar to a theater structure independent from the consciousness or intentions of social actors. From this perspective, people show several facets, sublimate their personal problems, adopt gestures of fellowship and kindness that can be articulated or accommodated together ${ }^{(5)}$.

This behavior identified in the speeches favors harmonious accommodation in the face of the situation of hospitalization. In this way, the family member uses the metaphor of dramatization of everyday life, thoughtlessness manifesting the mask of cunning and double-dealing that are important to ritualize everyday life. The mask does not mean falsity, but a possibility of protection ${ }^{(8)}$.

Dramatization is found in the fragments of speeches: "We do our best to fit into that situation" (Dalia); "because I leave my domestic problems at home" (Camellia). The use of masks can be mutant and is integrated to a wide range of scenes, situations that acquire value only when played as a whole, in the relationship with the other, in clusters ${ }^{(3)}$.

The everyday drama of the family members sharing a collective space corroborates with an equally collective emotion, where sensitivity transcends to rationality. Sensitivity in face of mutual problems and living in the same space maximizes affectual relations, solidarity, and sympathy. Taking care of the self and of the other is a hard task that demands articulation between people and places in the social micro-clusters ${ }^{(11)}$.

The solidarity present in these social micro-clusters, which was observed in the speeches by the actors in this study is expressed through generosity, mutual everyday assistance, consideration for the moments of suffering that occur in diseases, and other manifestations of human distresses ${ }^{(3)}$. Therefore, although the accompanying family member is physically and emotionally exhausted, they say this staying provides pleasure, satisfaction, and personal growth ${ }^{(12)}$.

In their discourses, the family members refer to clusters, bonds of friendship built in the environments of care, to the community of companions where sympathy and solidarity are aggregating factors.

The emotional communities are characterized by the lack of organization and an everyday structure. These forms of regrouping do not comply with or fit into the hardening of institutional rules. In this study, these aspects were evidenced by the constructing of bonds of friendship that remain after the hospital discharge of the relatives accompanied.

Links are established in the presence of the other, strengthened by the experience of suffering together, disseminated between the emotional links and becoming a special relationship that is not static. Emotions are ways of perceiving the main characteristics of a situation, giving it a meaning that would not exist without emotion. Emotions are recognized in the everyday, in crises where loss and risk are present, generate dependence and are hardly controlled, but the individual matures and develop over time ${ }^{(13)}$.

Family members interacting in micro-clusters present a feeling of belonging when they recognize themselves as groups, and start building bonds of solidarity and mutual help. This help is evident in the actions of care and wellbeing between them when they worry about the others' food, and with the provision of environmental resources that provide comfort and health therapy. Caregivers need the help of other family members to alternate in care to the self and to their hospitalized relatives ${ }^{(14)}$.

The supporting networks provided by relatives, friends, and professionals can promote adaptation to handle the disease ${ }^{(15)}$. In this way, continuity of support must be shown. Those living far from the hospital and who are far from their families or friends expect less help from their information network and, therefore, the family member in the environment of care becomes more dependent upon the others' support ${ }^{(2)}$.

However, this coexistence in the same place/space is not always free of conflicts. These conflicts are inherent to living in society, because the experience of staying in the hospital and being a caregiver in interaction processes triggers situations in family members that can be of disappointment, confusion, worry, and conflict ${ }^{(16)}$.

The sustaining of the social set points out that the other's experience serves as ground to the community, even if it is one of conflict. In this light, the emphasis placed on the place/space surrounded by the climate of the environment is not an end itself. This statement introduces the logic of fusion present in tactile relationships, where tribes can happen without the traditional dialogue, in a stippled union ${ }^{(3)}$.

The logic of fusion in tactile relationships was identified in the discourses of family members through the use of the Internet on their cell phones and through phone calls. The technological apparatus, typical of post-modern tribes, allows building feeling through relationships either in the physical or social levels ${ }^{(3)}$. These networks tend to strengthen family ${ }^{(17)}$.

The technological apparatus reaffirms the sense of belonging in what, in the comprehensive light, could be the model of a new global settlement. Technological resources 
such as the Internet have shown to be efficacious tools of support to family members in situations of anxiety and loneliness, and also in the communication process when it cannot be face-to-face ${ }^{(18)}$.

Communication is perceived as a general tendency, as something that will be the cause and effect of a specific spirit of time. Relationships can be of different kinds, favor micro-organization, and strengthen the will to participate, of concern about the community through the stripping of the self and the desire for fusion ${ }^{(5)}$.

Family members establish such deep relationships with the subject being cared for that they relinquish the self because of the other. In this context, caring is not an overload, but giving the self ${ }^{(7)}$, in a strong aesthetic or empathic load that connotes an organic want-to-live, like a set potency, a tribal vitalism ${ }^{(5)}$.

A living can be grounded on the communion found in small modulations, in a flexible crossing of several circles that, when articulated, build up the figures of sociality, the religiosity. Religiosity in the sense of reconnecting, in an organic connection in which nature, society, groups, and the mass interact ${ }^{(3)}$.

Connections are established through experiences and not only by the magnitude of care, as well as by the availability and efficacy of formal and informal supports (actual and imaginary), and by the accompanying family members' willingness to organically use this supporting structure ${ }^{(19)}$.

As such, to us this new way of social grouping is the emotional interlocution between accompanying family members. The scenarios of care presented different emotional characteristics; however, these bear similarities with the metaphor of tribe in their inner structure.

This study intends to awaken, in nursing, the need for thinking over the presence of family in the hospital environment-family as a plural group with its own structure, models and dynamics. Understanding this plurality and adopting professional behavior that comprises sensitiveness, availability to listen, and understanding the different ways that families express their suffering and anxiety can improve the family's quality of care.

\section{CONCLUSION}

In this study we understood that each accompanying family member actively participates in different tribes, notably: the tribe of origin; in the family place/space outside of the hospital environment; and the tribe with a strong emotional character, determined by the forced co-living in the environment of care. In these scenarios, these inner tribes interrelate, thus building the tribe in the emotional community where this interaction resembles villages.

The hospital environment triggers emotional ambience through mutual experiences. Living in the same place/ space developed, among the caregivers, relations of affection, solidarity behaviors grounded on sympathy, in this way becoming an emotional community, a community of companions.

Family members use masks such as cunning and double-dealing to establish harmony in cloudy moments of relationships. However, communion and the connection between them, jointly with the feeling of belonging, were found in all three scenarios, despite their different emotional characteristics.

The totem was another aspect common to these scenarios. The totem, represented by care-care of the relative and care of the self-as a factor of collective aggregation that rests on the needs of the relatives who are hospitalized and in their need for wellbeing in the hospital context. A ritualized care in the living of these family members that strengthens the group (tribe) interaction. In this way, the accompanying family member, in the process of group interaction, makes up a specific social group with feeling of belonging, typical to tribes.

\section{RESUMO}

Objetivo: Compreender o relacionamento no quotidiano dos familiares acompanhantes nos cenários de cuidado que se aproximam da metáfora da tribo no ambiente hospitalar. Método: Estudo qualitativo com dados coletados a partir de entrevistas semiestruturadas e observação com 16 familiares acompanhantes de pessoas hospitalizadas com dependência para o autocuidado. Os dados foram submetidos à análise temática e analisados através da metáfora da tribo proposta pela sociologia compreensiva. Resultados: Os familiares formam um agrupamento social em torno do cuidado onde encontramos as características das tribos: a ambiência emocional; a solidariedade baseada nos vínculos de simpatia e ajuda mútua; a nebulosa afetual no processo interacional; a lógica da fusão nas relações tácteis e a comunhão/religiosidade no processo de ligação numa identidade coletiva. Conclusão: Os familiares na presença do trágico criam agrupamentos sociais que se assemelham a tribos cujo totem é o cuidado.

\section{DESCRITORES}

Família; Relações Familiares; Hospitalização; Cuidadores; Relações Comunidade-Instituição.

\section{RESUMEN}

Objetivo: Comprender la relación en el cotidiano de los familiares acompañantes en los escenarios de cuidado que se acercan de la metáfora de la tribu en el ambiente hospitalario. Método: Estudio cualitativo con datos recogidos a partir de entrevistas semiestructuradas y observación con 16 familiares acompañantes de personas hospitalizadas con dependencia para el autocuidado. Los datos fueron sometidos al análisis temático y analizados por medio de la metáfora de la tribu propuesta por la sociología comprensiva. Resultados: Los familiares forman una agrupación social en torno al cuidado en donde encontramos las características de las tribus: el entorno emotivo; la solidaridad basada en los vínculos de simpatía y ayuda mutua; la nebulosa del afecto en el proceso interactivo; la lógica de la fusión en las relaciones táctiles y la comunión/religiosidad en el proceso de conexión en una identidad colectiva. Conclusión: Los familiares, ante la presencia de lo trágico, crean agrupaciones sociales que se asemejan a tribus cuyo tótem es el cuidado.

\section{DESCRIPTORES}

Familia; Relaciones Familiares; Hospitalización; Cuidadores; Relaciones Comunidad-Institución. 


\section{REFERENCES}

1. Kaplan SG, Arnold EM, Irby MB, Boles KA, Skelton JA. Family systems theory and obesity treatment: applications for clinicians. Infant Child Adolesc Nutr [Internet]. 2014 [cited 2016 Mar 25];6(1):24-9. Available from: http://www.ncbi.nlm.nih.gov/pmc/articles/PMC3979546/

2. Ownsworth T, Goadby E, Chambers SK. Support after brain tumor means different things: family caregivers' experiences of support and relationship changes. Front Oncol [Internet]. 2015 [cited 2016 Mar 25];5:33. Available from: http://www.ncbi.nlm.nih.gov/pmc/articles/ PMC4325881/

3. Maffesoli M. O tempo das tribos: o declínio do socialismo nas sociedades de massa. $4^{\mathrm{a}}$ ed. Rio de Janeiro: Forense Universitária; 2010.

4. Baumbusch J, Phinney A. Invisible hands: the role of highly involved families in long-term residential care. J Fam Nurs. 2014;20(1):73-97.

5. Maffesoli M. No fundo das aparências. Petropólis: Vozes; 1996.

6. Cabral BPAL, Nunes CMP. Percepções do cuidador familiar sobre o cuidado. Rev Ter Ocup Univ São Paulo [Internet]. 2015 [citado 2016 mar. 24];26(1):118-27. Disponível em: http://www.revistas.usp.br/rto/article/viewFile/79939/96384

7. Ferré-Grau C, Casado MS, Cid-Buera D, LLeixà-Fortuño M, Monteso-Curto P, Berenguer-Poblet M. Caring for family caregivers: an analysis of a family-centered intervention. Rev Esc Enferm USP [Internet]. 2014 [cited 2015 May 28];48(n.spe):87-94. Available from: http://www. scielo.br/pdf/reeusp/v48nspe/0080-6234-reeusp-48-esp-089.pdf

8. Rodríguez-Borrego MA, Nitschke RG, Prado ML, Martini JG, Guerra-Martín MD, González-Galán C. Theoretical assumptions of Maffesoli's sensitivity and problem-based learning in nursing education. Rev Latino Am Enfermagem [Internet]. 2014 [cited 2015 May 26];22(3):50410. Available from: http://www.ncbi.nlm.nih.gov/pmc/articles/PMC4292623/

9. Caswell G, Pollock K, Harwood R, Porock D. Comunication between family carers and health professionals about end-of-life care for older people in the acute hospital setting: a qualitative study. BMC Palliat Care [Internet]. 2015 [cited 2016 Mar 24];14:35. Available from: http:// www.ncbi.nlm.nih.gov/pmc/articles/PMC4522056/

10. Giraldo YN, Ruiz-Silva A. La comprensión de la solidaridad. Análisis de estudios empíricos. Rev.latinoam.cienc.soc.niñez juv [Internet]. 2015 [cited 2016 mar 26]; 13(2): 609-625.

11. Silva NMA, Freitas AS. A ética do cuidado de si no campo pedagógico brasileiro: modos de uso, ressonâncias e desafios. Pro-Posições [Internet]. 2015 [citado 2016 mar. 25];26(1):217-33. Disponível em: http://www.scielo.br/pdf/pp/v26n1/0103-7307-pp-26-01-0217.pdf

12. Lund L, Ross L, Petersen MA, Groenvold M. Cancer caregiving tasks and consequences and their associations with caregiver status and the caregiver's relationship to the patient: a survey. BMC Cancer [Internet]. 2014 [cited 2015 May 26];14:541. Available from: http://www. ncbi.nlm.nih.gov/pmc/articles/PMC4122762/

13. Fuchs T, Koch SC. Embodied affectivity: on moving and being moved. Front Psicol. [Internet]. 2014 [cited 2015 May 26];5:508. Available from: http://www.ncbi.nlm.nih.gov/pmc/articles/PMC4047516/

14. Costa SRD, Castro EAB. Autocuidado do cuidador familiar de adultos ou idosos dependentes após a alta hospitalar. Rev Bras Enferm [Internet] 2014 [citado 2016 mar. 27];67(6):979-86. Disponível em: http://www.scielo.br/pdf/reben/v67n6/0034-7167-reben-67-06-0979.pdf

15. Wicke FS, Güthlin C, Mergenthal K, Gensichen J, Löffler C, Bickel H, et al. Depressive mood mediates the influence of social support on health-related quality of life in elderly, multimorbid patients. Fam Prática BMC [Internet] 2014 [cited May 27]; 15:62. Available from: http://www.ncbi.nlm.nih.gov/pmc/articles/PMC3984397/

16. Fukuda R, Shimizu Y, Seto N. Issues experienced while administering care to patients with dementia in acute care hospitals: a study based on focus group interviews. Int J Qual Stud Health Well-being [Internet]. 2015 [cited 2016 Mar 26];10:25828. Available from: http://www. ncbi.nlm.nih.gov/pmc/articles/PMC4340824/

17. Anjos KF, Boery RNSO, Pereira R. Qualidade de vida de cuidadores familiares de idosos dependentes no domicílio. Texto Contexto Enferm [Internet]. 2014 [citado 2015 maio 27];23(3):600-8. Disponível em: http://www.scielo.br/pdf/tce/v23n3/pt_0104-0707-tce-23-03-00600.pdf

18. Bernal TAI. Tecnología, redes sociales, política y periodismo.i Pluralidad informativa o efecto bumerán? Cuad Inf [Internet]. 2015 [citado 2016 mar. 25];(36):191-205. Disponible en: http://www.scielo.cl/pdf/cinfo/n36/art13.pdf

19. Donovan R, Williams AM. Care-giving as a Canadian-Vietnamese tradition: 'it's like eating, you just do it'. Health Soc Care Community. 2015;23(1):79-87. 